\author{
References \\ 1. Stange KC, Zyzanski SJ. Integrating qualitative and quantitative \\ research methods. Fam Med. 1989;21(6):448-451. \\ 2. Contemporary challenges for practice-based research networks. Ann \\ Fam Med 2005;3(Suppl 1):S2-S60. \\ 3. Miller WL, McDaniel RR Jr, Crabtree BF, Stange KC. Practice jazz: \\ understanding variation in family practices using complexity sci- \\ ence. J Fam Pract. 2001;50(10):872-878. \\ 4. Macaulay AC, Commanda LE, Freeman WL, et al; North American \\ Primary Care Research Group. Participatory research maximises \\ community and lay involvement. BMJ. 1999;319(7212):774-778. \\ 5. Shaw EK, Ohman-Strickland PA, Piasecki A, et al. Effects of facili- \\ tated team meetings and learning collaboratives on colorectal can- \\ cer screening rates in primary care practices: a cluster randomized \\ trial. Ann Fam Med. 2013;11(3):220-228. \\ 6. Merton RK. The unanticipated consequences of purposive socia \\ action. Am Sociol Rev. 1936;1:894-904.
}

7. Abdel-Wahab MF, Strickland GT, El-Sahly A, El-Kady N, Zakaria S, Ahmed L. Changing pattern of schistosomiasis in Egypt 1935-79. Lancet. 1979;2(8136):242-244.

8. Hilbink M, Voerman G, van Beurden I, Penninx B, Laurant M. A randomized controlled trial of a tailored primary care program to reverse excessive alcohol consumption. J Am Board Fam Med. 2012;25(5):712-722.

9. Fernald DH, Dickinson LM, Froshaug DB, et al. Improving multiple health risk behaviors in primary care: lessons from the Prescription for Health Common Measures, Better Outcomes (COMBO) study. J Am Board Fam Med. 2012;25(5):701-711.

10. Weijer C, Grimshaw JM, Taljaard M, et al. Ethical issues posed by cluster randomized trials in health research. Trials. 2011;12:100.

11. Binik A, Weijer C, McRae AD, et al. Does clinical equipoise apply to cluster randomized trials in health research? Trials. 2011;12:118.

12. McRae AD, Weijer $C$, Binik $A$, et al. Who is the research subject in cluster randomized trials in health research? Trials. 2011;12:183.

\title{
EDITORIAL
}

\section{Practice Transformation? Opportunities and Costs for Primary Care Practices}

\author{
James M. Gill, MD, MPH, Associate Editor ${ }^{1}$ \\ Bruce Bagley, $M D^{2}$ \\ 'Delaware Valley Outcomes Research, Newark, Delaware \\ ${ }^{2}$ TransforMED, Leawood, Kansas
}

Ann Fam Med 2013;11:202-205. doi:10.1370/afm.1534.

$\mathrm{F}$ or the first time in recent history, there is nearly universal agreement that the redesigned US health care system must have as its foundation robust, comprehensive, and capable primary care. For this to happen, primary care practices need to make practice changes along the model of the patient-centered medical home (PCMH) ${ }^{1,2}$ Although this process of transformation provides exciting opportunities for practices, it also presents challenges, including costs. In this editorial, we discuss those opportunities, as

Conflicts of interest: authors report none.

\section{CORRESPONDING ADDRESS}

James M. Gill, MD, MPH

Delaware Valley Outcomes Research

17 Henderson Hill Rd

Newark, DE 19711

gillj@dvoresearch.com well as the challenges and costs and who should pay those costs.

There are many reasons for practices to move toward new ways of organizing care, even as they work to remain true to the core values of primary care and family medicine..$^{2-6}$ Internal reasons, driven by professionalism, include (1) becoming more service oriented for patients, (2) providing more effective care for better patient outcomes, (3) providing more efficient care for a better practice bottom line, and (4) creating an enjoyable work environment. External reasons for transformation are to position the practice to be successful in a new payment environment and to meet the needs of a changing patient population and emerging community needs.

Several articles in this issue of the Annals illustrate success in transformation efforts. Sinsky et al describe a team-based approach that could help restore joy in practice. ${ }^{7}$ Donahue et al describe a number of practices that succeeded in quality improvement initiatives. ${ }^{8}$ 
These articles also describe challenges that practices face in transformation. For example, Donahue et al found that some practices engaged in transformation were not successful. ${ }^{8}$ Shaw et al found no improvement in overall colorectal cancer screening rates for practices engaged in a quality improvement initiative. ${ }^{9}$

What does it take to make practice change a success? First, complete transformation requires a change in many independent processes to create a more efficient and effective whole. It is incomplete to add only a care coordinator or install electronic health records to improve quality or to add more medical assistants to see patients with the clinician. Complete transformation requires careful attention to 4 areas: leadership, teamwork, communication, and metrics. Without these basic organizational requirements, no amount of practice facilitation or coaching is likely to succeed.

Transformation also costs money and human resources. Donahue et al suggest 2 to 3 clinical support staff per physician for effective team-based care, a much higher ratio than is found in most practices. Funding is also needed to support quality improvement efforts. Culler et al estimated the cost of a practice facilitator for improving diabetes management at nearly $\$ 10,000$ per practice per year, which does not include costs to the practice for staff and systems. ${ }^{10}$

What do these practice change activities cost the practice? A study by Dodoo et al found that improving care through behavior interventions cost practices an average of $\$ 1,850$ per month for implementation, plus $\$ 58$ per month for each patient that participated in the intervention. ${ }^{11}$ For a practice with several interventions that include $20 \%$ of a physician's panel of 1,500 patients, the monthly cost could be more than $\$ 17,000$ per physician. Halladay et al found that just the process of reporting on quality cost an average of $\$ 5,600$ per clinician for start-up, plus $\$ 2,200$ annually. ${ }^{12}$

Given that transformation requires many of these activities, it is important for practices to know what their total costs would be. Although many articles describe transformation programs, including 14 articles in a recent Annals supplement, ${ }^{13}$ few explore costs to practices. A recent analysis by Baron et al suggested that changing to a PCMH model would cost practices approximately $\$ 117,000$ per physician per year. ${ }^{14}$ Some of these costs might be reduced through more efficient work flow. For example, some studies find that increasing the staff-tophysician ratio can increase net revenue to practices. ${ }^{15}$ Other authors, however, suggest that the costs might actually be higher, and that most practices underestimate the costs of practice change. ${ }^{16}$ Uncertainty about the cost to practices is one reason that the Agency for Healthcare Research and Quality is funding studies to examine the full cost of primary care transformation. ${ }^{17}$
Who should bear these transformation costs? Some might argue that they should be borne by practices, because they are opportunity costs for participation in a changing business environment. In fact, some practices have tried to offset these costs by increasing efficiency or focusing on procedures with higher reimbursement. Most practices, however, are capital depleted and lack the administrative infrastructure to support systematic improvement and change. In other industries businesses could recoup these opportunity costs by increasing their prices, but such is not a viable option for primary care practices, which have limited ability to set their prices. Even if practice change ultimately engenders efficiencies, during the transition period practices with often miniscule margins need to pay real and often substantial costs. ${ }^{18}$ It is impractical to expect primary care practices to bear the cost of transformation unless they are reimbursed for the costs they incur.

Research on the PCMH has shown that the ultimate savings for this investment accrues not to the practice but to patients, payers, and the health care system. ${ }^{19,20}$ The health care system, therefore, needs to invest in helping practices to make the changes that are needed for an effective, efficient, patient-centered, and sustainable health care system. Currently about 5\% to 6\% of US health care expenditures go to primary care. ${ }^{21}$ The American Academy of Family Physicians (AAFP) has advocated for payers to increase allocation to $10 \%$ to $12 \%$ of expenditures, ${ }^{22}$ similar to countries where overall costs are lower and quality is higher. Increasing payment to primary care can dramatically reduce the total cost of care as long as these resources are funneled into systematic changes in the process and conduct of the care. A study by Raskas et al showed that a 20\% increase in payment to primary care would only be $1 \%$ of total costs but can save $4 \%$ from the total spent. ${ }^{23} \mathrm{~A}$ report of US PCMH programs showed major improvements in quality of care, including diabetes and other chronic disease care, as well as preventive care. ${ }^{24}$ It also showed that payers saved much more than they spent for transformation. These savings could be used to pay for the cost of practice transformation, as well as reduce the disparity in pay between primary care physicians and their specialty colleagues.

Changes in payment to primary care should include not only how much is paid but also how it is it paid. In the current fee-for-service payment system that rewards volume rather than quality, we cannot expect substantial change in how the work of primary care is accomplished. The Commonwealth Fund, ${ }^{25}$ AAFP, $^{22}$ and other organizations and individuals ${ }^{26-28}$ have called for a blended model of payment, combining fee-for-service with capitated payments for care coordination and bonuses for performance and/or shared cost savings. 
Payers can also provide support by paying for systems to coordinate care between primary care offices and other components of the health care system.

Some payers are recognizing this need to support primary care in order to achieve transformation. For example, Medicare is paying primary care clinicians a $10 \%$ bonus for office visits, in addition to paying bonuses for the Physician Quality Reporting System, e-prescribing, and meaningful use of electronic health records. Care First Blue Cross Blue Shield has paid primary care clinicians an average of 32\% higher rates in its $\mathrm{PCMH}$ program, with practices eligible for even higher payments based on performance standards. In early 2012, WellPoint, Aetna, and United, all announced plans to pay primary care in a different way with overall higher payments.

Although these programs are helpful, they are unlikely to be sufficient in isolation, because offices cannot transform only for patients with selected insurance plans. Payment reform needs to occur for all payers to make transformation feasible for practices. The Comprehensive Primary Care (CPC) initiative of the Centers for Medicare \& Medicaid Services Innovation Center exemplifies such a multipayer program. ${ }^{29}$ Practices receive the usual fee-for-service payment plus a prepaid care management fee that averages $\$ 20$ per member per month for Medicare patients (with a lesser amount from commercial payers that have younger and less complex patients) in exchange for meeting discreet transformation milestones. In addition, there is the opportunity for shared savings after data are available for the first full year.

Even though the CPC initiative is operational in only 7 markets, the Secretary of Health and Human Services has the authority to make these same changes in the entire Medicare program without further legislation. If other payers follow, this program should serve as a model for multipayer payment and transformation support throughout the United States. The care coordination component is particularly important because it rewards quality rather than volume and focuses on what primary care clinicians are uniquely qualified to do. It also provides adequate payment to support transformation-meeting the cost estimates of Baron ${ }^{14}$ and Dodoo et $\mathrm{al}^{11}$ would require about $\$ 7$ to $\$ 12$ per patient per month averaged across all patients and payers. Higher monthly payments would be needed to reduce the specialty payment gap if not all payers participated.

The US health care system is at a dramatic crossroad. The current model, based on volume rather than value, is unsustainable. The alternative is a system that fosters a shared sense of responsibility for cost, quality, and service. This alternative presents a tremendous opportunity for primary care. A transition is not pos- sible without robust primary care, which will require transformation along the PCMH model.

For the needed changes to occur on a wide and sustainable basis, the cost to primary care practices should be funded by payers. Primary care clinicians should be held accountable for providing value to patients rather than volume of services, but they should be paid for the value they provide. We must not repeat the mistakes of the managed care era of the 1990s, where primary care physicians ceded the initiative to payers and promised unrealistic changes for inadequate support. Trying to fully transform primary care practice with inadequate funding is akin to using a 4 -foot rope to save someone stuck in a 12 -foot hole. If adequately funded, primary care practices can take the lead in reforming the US health care system by transforming their practices along the PCMH model. This transformation promises to not only "restore the joy in practice" but also to attract the best and brightest medical students to primary care.

To read or post commentares in response to this article, see it online at http://www.annfammed.org/content/11/3/202.

Key words: practice transformation; practice costs, delivery of health care; practice management

Submitted March 26, 2013; submitted, revised March 26, 2013; accepted March 26, 2013.

Acknowledgments: The authors would like to thank Miranda Moore, PhD, from the Robert Graham Center for Policy Studies, for her helpful comments and references.

\section{References}

1. Landon BE, Gill JM, Antonelli RC, Rich EC. Prospects for rebuilding primary care using the patient-centered medical home. Health Aff (Millwood). 2010;29(5):827-834.

2. Stange KC, Nutting PA, Miller WL, et al. Defining and measuring the patient-centered medical home. J Gen Intern Med. 2010;25(6):601-612.

3. Stange $K C$, Jaén $C R$, Flocke SA, Miller WL, Crabtree BF, Zyzanski SJ. The value of a family physician. J Fam Pract. 1998;46(5):363-368.

4. Donaldson MS, Lohr KN, Vanselow NA, eds. Primary Care: America's Health in a New Era. Washington, DC: National Academy Press; 1996.

5. Starfield B. Primary Care: Balancing Health Needs, Services, and Technology. Rev. ed. New York, NY: Oxford University Press; 1998.

6. McWhinney IR, Freeman T. Textbook of Family Medicine. 3rd ed. New York, NY: Oxford University Press; 2009.

7. Sinsky CA, Willard-Grace R, Schutzbank AM, Sinsky TA, Margolius D, Bodenheimer $T$. In search of joy in practice: a report of 23 high-functioning primary care practices. Ann Fam Med. 2013;11(3);272-277.

8. Donahue KE, Newton WP, Lefebvre A, Plescia M. Natural history of practice transformation: development and initial testing of an outcomes-based model. Ann Fam Med. 2013;11(3):212-219.

9. Shaw EK, Ohman-Strickland PA, Piasecki A, et al. Effects of facilitated team meetings and learning collaboratives on colorectal cancer screening rates in primary care practices: a cluster randomized trial. Ann Fam Med. 2013;11(3):220-228. 
10. Culler SD, Parchman ML, Lozano-Romero R, et al. Cost estimates for operating a primary care practice facilitation program. Ann Fam Med. 2013;11(3):207-211.

11. Dodoo MS, Krist AH, Cifuentes M, Green LA. Start-up and incremental practice expenses for behavior change interventions in primary care. Am J Prev Med. 2008;35(5)(Suppl):S423-S430.

12. Halladay JR, Stearns SC, Wroth T, et al. Cost to primary care practices of responding to payer requests for quality and performance data. Ann Fam Med. 2009;7(6):495-503.

13. Gill JM, Cohen DJ, guest eds. Transforming primary care practice. Ann Fam Med. 2013;11(Suppl);S1-S123.

14. Baron R. Implementing the PCMH: The practice experience. Washing ton, DC: PCPCC Stakeholders' Working Meeting; 2008.

15. Day J, Scammon DL, Kim J, et al. Quality, satisfaction, and financial efficiency associated with elements of primary care practice transformation: preliminary findings. Ann Fam Med. 2013;11(Suppl);S50-S59.

16. Krist AH, Cifuentes M, Dodoo MS, Green LA. Measuring primary care expenses. J Am Board Fam Med. 2010;23(3):376-383.

17. Agency for Health Care Research and Quality. Announcements. http://www.ahrq.gov/funding/research/announcements/index.html. Accessed Mar 21, 2013.

18. Spann SJ; Task Force 6 and the Executive Editorial Team. Report on financing the new model of family medicine. Ann Fam Med. 2004;2(Suppl 3):S1-S21.

19. Reid RJ, Coleman K, Johnson EA, et al. The Group Health medical home at year two: cost savings, higher patient satisfaction, and less burnout for providers. Health Aff (Millwood). 2010;29(5):835-843.

20. Reid RJ, Fishman PA, Yu O, et al. Patient-centered medical home demonstration: a prospective, quasi-experimental, before and after evaluation. Am J Manag Care. 2009;15(9):e71-e87.
21. Phillips RL Jr, Bazemore AW. Primary care and why it matters for U.S. health system reform. Health Aff (Millwood). 2010;29(5):806-810.

22. Goertz RA. American Academy of Family Physicians. Medicare reinbursement to physicians [web page]. http://www.aafp.org/online/en/ home/policy/federal/issues/reform/payment/statements/medicarereimb.html.

23. Raskas RS, Latts LM, Hummel JR, Wenners D, Levine $H$, Nussbaum SR. Early results show WellPoint's patient-centered medical home pilots have met some goals for costs, utilization, and quality. Health Aff (Millwood). 2012;31(9):2002-2009.

24. Nielsen M, Langer B, Zema C, Hacker T, Grundy P. Benefits of Implementing the Primary Care Patient-Centered Medical Home: PatientCentered Primary Care Collaborative; 2012.

25. Davis K. Investing in health care reform. N Engl J Med. 2009;360 (9):852-855.

26. Berenson RA, Rich EC. US approaches to physician payment: the deconstruction of primary care. J Gen Intern Med. 2010;25(6):613-618

27. Berenson RA, Rich EC. How to buy a medical home: or let a thousand options bloom? How about five? Patient-Centered Medical Home: Setting a Policy Agenda; 2009.

28. Goroll AH, Berenson RA, Schoenbaum SC, Gardner LB. Fundamenta reform of payment for adult primary care: comprehensive payment for comprehensive care. J Gen Intern Med. 2007;22(3):410-415.

29. Centers for Medicare \& Medicaid Services. Comprehensive Primary Care Initiative http://innovation.cms.gov/initiatives/comprehensiveprimary-care-initiative/. Accessed Mar 21, 2013.

\section{EDITORIAL}

\section{The Wonder and the Mystery: Your Voices, Your Stories}

Robin S. Gotler, MA, Reflections Editor

Ann Fam Med 2013;11:205-206. doi:10.1370/afm.1535.

$\mathrm{T}$ he Annals is proud to announce the publication of its first book: The Wonder and the Mystery: 10 Years of Reflections from the Annals of Family

Medicine. ${ }^{1}$

The Wonder and the Mystery is an anthology of intimate personal stories and innovative ideas published in the Annals' Reflections section. It includes a wide range of articles, from influential pieces on urgent topical issues to exceptional stories of unique individuals. The stories shed light on small moments and major life transitions. In the process, they help us find meaning in our own physical, emotional, and spiritual journeys.
Together, the articles in The Wonder and the Mystery deepen our understanding of "the vibrant, unpredictable place where primary care and life intersect." 2 This unique collection is framed by the insights of Rachel Naomi Remen, whose Foreword might just remind readers of the "sense of wonder, of awe, of aliveness" that drew them to primary care.

Sharing reflections is an integral part of the Annals' effort to shed light on the core of family medicine and primary care. When clinicians, researchers, and patients allow us a glimpse into their thoughts, practices, and lives_-their personal and professional stories_-we are 